\title{
Biodiversitas Mikroba Rizosfer Tanaman Jeruk Keprok Borneo Prima (Citrus reticulata cv Borneo Prima)
}

\section{Biodiversity of Rizhosfer Microbe Borneo Prima Orange Plant (Citrus reticulata cv Borneo Prima)}

\author{
Purwati $^{1}$, Hamidah ${ }^{1}$ \\ ${ }^{1}$ Tenaga Pendidik Program Studi Agroteknologi, Fakultas Pertanian, Universitas Widya Gama Mahakam \\ Jl. KH. Wahid Hasyim, Sempaja, Samarinda, Kalimantan Timur, Indonesia \\ email : purwati@uwgm.ac.id, hamidah@uwgm.ac.id
}

Diterima : 22 Agustus 2018 Disetujui : 12 Oktober 2018

\begin{abstract}
Borneo Prima tangerine (Citrus reticulata cv Borneo Prima) is an indigenous plant from Tanjung Labu Village, Rantau Pulung District, East Kutai District, East Kalimantan Province. In the cultivation of these plants, there are pathogens that can cause a decrease in crop yields. This study aims to identify the diversity of rhizosphere microbial populations in Borneo Prima tangerine plants. The study was conducted at the Laboratory of Plant Pests and Diseases of the Faculty of Agriculture, Mulawarman University Samarinda in February-April 2018. This study was descriptive, using a survey method. The study consisted of two stages, namely (1) soil sampling on Borneo Prima tangerine citrus land in Makroman Village, Kutai Kartanegara Regency, East Kalimantan (2) isolation, characterization, identification, gram test, in the Laboratory of Pests and Plant Diseases. The data obtained were analyzed using quantitative descriptive analysis. The results of the study of the isolation of rhizosphere microbes in Borneo Prima tangerine citrus plants obtained 1 family of bacteria namely Azotobacteraceae and 4 fungal genera including Aspergilus, Mucor, Penicillium and Trichoderma. Microbes that belong to the group that benefit the soil ecosystem are Azotobacteraceae because they play a role in fixing (fixation) N2 or as biofertilizers. While the genus Mucor and Penicillium act as decomposers and Trichoderma acts as a controller of pathogens or biological agents and biological pesticides (biopestiside).
\end{abstract}

Key words: Biodiversity, Rhizosfer, Borneo Prima Orange

\section{PENDAHULUAN}

Jeruk keprok Borneo Prima merupakan salah satu komoditas hortikultura unggulan baru di Kalimantan Timur, yang memiliki keunggulan sebagai jeruk keprok dataran rendah dengan kulit buah berwarna jingga (BPPMD Kaltim, 2009).

Rhizosfer merupakan bagian tanah yang berada di sekitar perakaran tanaman. Populasi mikroba pada rhizosfer umumnya lebih banyak dan beragam dibandingkan pada tanah nonrhizosfer. Aktivitas mikroba pada rhizosfer dipengaruhi oleh eksudat yang dihasilkan oleh perakaran tanaman. Beberapa mikroba pada rhizosfer berperan dalam siklus hara, proses pembentukan tanah, pertumbuhan tanaman, mempengaruhi aktivitas mikroorganisme, dan sebagai pengendali hayati terhadap patogen akar (Simatupang, 2008).

Upaya penggalian jenis mikroba pada rhizosfer tanaman jeruk keprok Borneo Prima tersebut belum banyak dilakukan. Untuk itu dilakukan penelitian mengenai potensi mikroba terutama yang berhubungan dengan kesuburan tanah dan pengendali patogen tanah. Identifikasi merupakan suatu kegiatan yang sangat penting mengingat banyak jenis mikroba belum diketahui jumlah dan jenisnya. Tingkat kesuburan tanah di lahan jeruk keprok Borneo Prima perlu diketahui sehingga perlu didukung dengan data dan informasi tentang mikroba tanah yang terdapat di lahan tersebut.

Bakteri yang berperan dalam meningkatkan kesuburan tanah dikenal sebagai biofertilizer karena dapat meningkatkan efisiensi penggunaan pupuk anorganik, sehingga sangat menunjang sistem pertanian yang berwawasan lingkungan (Susilowati et al., 2003). Dalam hal penyediaan dan penyerapan unsur hara bagi tanaman, aktivitas mikroba diperlukan untuk menjaga ketersediaan tiga unsur hara yang penting bagi tanaman antara lain, nitrogen $(\mathrm{N})$, fosfat (P), dan kalium (K). Kurang lebih $80 \%$ kandungan udara adalah $\mathrm{N}$ (Metasari, 2011).

Berdasarkan uraian tersebut, maka perlu dilakukan penelitian untuk mengidentifikasi biodiversitas populasi mikroba rizosfer pada tanaman jeruk keprok Borneo Prima sehingga dapat digunakan sebagai pengelolaan teknik budidaya yang tepat. Penelitian ini bertujuan untuk mengetahui biodiversitas mikroba baik jumlah dan jenisnya serta untuk mendapatkan 
isolat murni yang dapat dikembangkan sebagai sumber plasma nutfah mikroba penyubur tanah

\section{BAHAN DAN METODE}

Penelitian dilakukan dengan metode isolasi tanah rhizosfer secara langsung dari daerah perakaran / rhizosfer tanaman jeruk keprok Borneo Prima dari lahan perkebunan masyarakat di Kelurahan Makroman Kabupaten Kutai Kartanegara Provinsi Kalimantan Timur. Pemurnian jamur dan identifikasinya dilakukan di Laboratorium Hama dan Penyakit, Fakultas Pertanian, Universitas Mulawarman Samarinda. Mulai bulan Februari-April 2018. Bahan yang digunakan dalam penelitian ini adalah tanah dari rizosfer tanaman jeruk keprok

\section{HASIL DAN PEMBAHASAN}

Hasil penelitian isolasi mikroba rizosfer tanaman jeruk keprok Borneo Prima diperoleh 1 famili bakteri yaitu Azotobacteraceae dan 4 genus jamur meliputi Aspergilus, Mucor, Penicillium dan Trichoderma. Hasil isolasi mikroba pada rhizosfer tanaman jeruk keprok Borneo Prima dapat dilihat pada Gambar 1 dan Gambar 2. Mikroba merupakan alternatif dalam pengendalian hama dan penyakit tanaman yang sangat potensial sehingga dapat dimanfaatkan sebagai pengganti pestisida. Keuntungan penggunaan pestisida hayati yaitu ekonomis dan ramah lingkungan. Ditambahkan oleh Powell \& Faull (1989) bahwa pertimbangan dalam memilih agen pengendali hayati yaitu kemampuan biopestisida bertahan dalam waktu lama dan tidak memerlukan tempat penyimpanan khusus.

Sifat fisik dan kimia yang baik memiliki ciri-ciri mengandung berbagai macam mikroba. Pada umumnya mikroba yang terdapat dalam tanah antara lain bakteri penambat nitrogen nonsimbiotik.

Mikroba yang berperan dalam penyedia unsur hara di dalam tanah (biofertilizer) yaitu dikelompokkan sebagai penyedia unsur $\mathrm{N}$ dan pelarut $\mathrm{P}$ (Phosphorus solubilizing organism). Mikroorganisme bakteri yang terdapat pada rhizosfer tanaman pisang rutai yang tergolong ke dalam kelompok penyedia unsur $\mathrm{N}$ adalah Azotobacteraceae sedangkan yang tergolong ke dalam kelompok pelarut $\mathrm{P}$ adalah Bacillaceae (Prihartini, 1990 dalam Syarifudin, 2002).

Azotobacteraceae dapat dijumpai pada semua tanah sehingga dapat dikatakan sebagai spesies yang umum terdapat di rhizosfer tanaman pisang rutai. Bakteri ini berperan dalam mengikat (fiksasi) $\mathrm{N}_{2}$ di udara (biofertilizer) dan dan pengendali pathogen tanah pada tanaman jeruk keprok Borneo Prima.

Borneo Prima, Alkohol 70\%, $\mathrm{NaOCl} 5 \%$, media Potato Dextrose Agar (PDA), spirtus, dan aquades steril.Penelitian menggunakan metode deskriptif. Penelitian terdiri dari dua tahap, yaitu (1) pengambilan sampel tanah pada lahan pertanaman pisang rutai di Kecamatan Muara Badak Kabupaten Kutai Kartanegara, Kalimantan Timur (2) isolasi dan identifikasi di Laboratorium HPT Unmul. Pengamatan dilakukan terhadap keragaman mikroba tanah pada rhizosfer tanaman jeruk keprok Borneo Prima yaitu keragaman bakteri dan jamur meliputi jenis dan jumlah populasi.

memacu pertumbuhan tanaman (Goenadi, 1997 dalam Syarifudin, 2002). Famili Azotobacteraceae, memiliki ciri-ciri meliputi sel serupa batang, bola atau telur, tidak mempunyai endospora, gram negatif, aerob, dan hidup bebas dalam tanah.

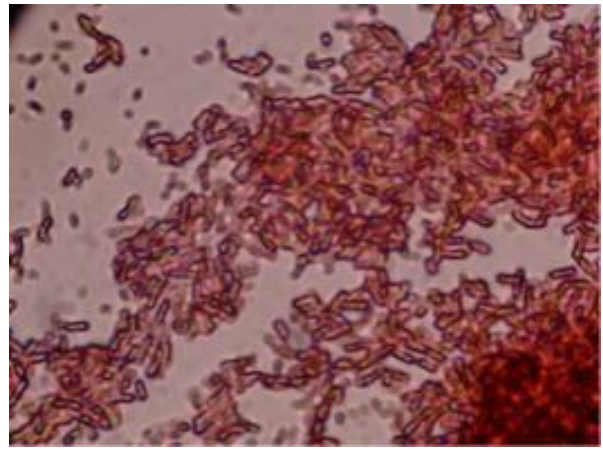

Gambar 1. Bakteri : Famili Azotobacteraceae

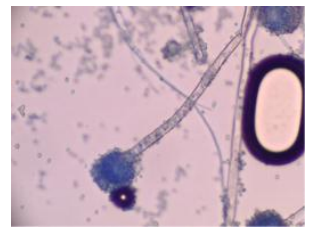

$2 \mathrm{a}$

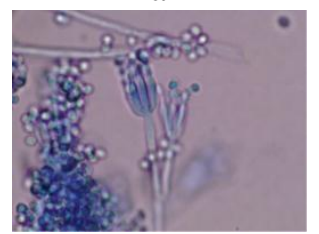

$2 \mathrm{c}$

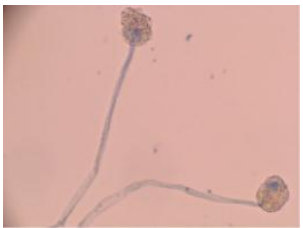

$2 b$

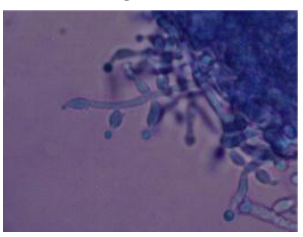

$2 \mathrm{~d}$
Gambar 2. Jamur: Genus Aspergilus (2a), Mucor (2b), Penicillium (2c) dan Trichoderma (2d). 
Azotobacter memiliki kelebihan dibandingkan dengan bakteri penambat $\mathrm{N}$ nonsimbiotik lainnya karena mampu mensintesis hormon seperti IAA (Indole Acetic Acid) sehingga dapat memacu pertumbuhan tanaman (Widiastuti dkk, 2010).

Kemampuan bakteri penambat nitrogen nonsimbiotik pada rhizosfer tanaman untuk mengikat nitrogen lebih maksimal dipengaruhi oleh faktor-faktor diantaranya $\mathrm{pH}$ tanah, aerasi, drainase yang baik, kelembaban, kandungan bahan organik, serta kondisi perakaran tumbuhan tingkat tinggi tempatnya hidup juga akan memengaruhi keragaman dan populasi bakteri penambat $\mathrm{N}$ non-simbiotik (Agustian et al. 2012).

Jamur Trichoderma sp dapat dimanfaatkan sebagai jamur antagonis patogen tanah dapat berkembang biak dengan cepat pada daerah perakaran tanaman. Beberapa penelitian menunjukkan bahwa Trichoderma, Penicillium dan Aspergillus adalah jamur antagonis yang dapat berperan sebagai biopesticide maupun biofertilizer karena mengeluarkan zat sejenis antibiotik tertentu atau metabolit sekunder untuk menekan perkembangan patogen. Selain itu juga dapat berperan sebagai deKomposer untuk meningkatkan kesuburan tanah sehingga memicu pertumbuhan tanaman (Khan et al., 2008; Vinale et al., 2008; Song et al., 2010; Sudantha dkk., 2011).

Mekanisme yang dilakukan oleh jamur antagonis Trichoderma sp. terhadap patogen adalah mikoparasit yaitu mampu menekan

\section{KESIMPULAN}

1. Hasil isolasi mikroba rizosfer tanaman jeruk keprok Borneo Prima diperoleh bakteri yaitu Famili Azotobacteraceae dan Jamur terdapat 4 genus meliputi Aspergilus, Mucor, Penicillium dan Trichoderma.

2. Famili Azotobacteraceae berperan dalam penambatan (fiksasi) $\mathrm{N}_{2}$ atau sebagai biofertilizer

3. Genus Mucor dan Penicillium berperan sebagai decomposer serta Trichoderma berperan sebagai pengendali patogen atau sebagai (biological agens) dan pestisida hayati (biopestiside).

1. sebagai pengendali patogen (biological agens) dan sebagai pestisida hayati (biopestide).

\section{DAFTAR PUSTAKA}

Agustian, Syafei R, Maira L. 2012. Keragaman Bakteri Penambat $N$ pada Rhizosfer Titonia aktivitas patogen tular tanah dan kompetitor baik ruang maupun nutrisi (Sudantha dkk., 2011). Jamur Trichoderma sp. memiliki beberapa kelebihan yaitu mudah diisolasi, daya adaptasi luas, dapat tumbuh dengan cepat pada berbagai substrat, memiliki kisaran mikroparasitisme yang luas dan tidak bersifat patogen pada tanaman (Arwiyanto, 2003).

Erwanti (2003) menyatakan bahwa, pengendalian hayati bersifat spesifik lokal yaitu mikroorganisme antagonis yang terdapat di suatu daerah hanya akan memberikan hasil yang baik di daerah asalnya. Jamur adalah Aspergilus sp tergolong ke dalam kelompok pelarut $\mathrm{P}$ (Prihartini, 1990 dalam Syarifudin, 2002). Goenadi (1997) dalam Syarifudin (2002) menjelaskan bahwa Aspergilus sp berperan dalam meningkatkan efisiensi penyerapan unsur hara oleh akar tanaman melalui peningkatan kelarutan unsur hara yang dibutuhkan oleh tanaman.

Mikroba memiliki kemampuan menempati berbagai habitat sehingga memiliki kesempatan untuk berkembang biak. Di sekitar perakaran terdapat bahan-bahan organik dari eksudat akar tanaman yang dapat digunakan mikroba sebagai sumber makanan. Jumlah dan jenis mikroba pada tanah disebabkan oleh faktor suhu, keterbatasan makanan dan aktivitas manusia diantaranya pemupukan dan penggunaan pestisida yang terus-menerus di lahan pertanian sehingga kehidupan mikroorganisme terganggu.

(Tithonia Diversifolia) yang Tumbuh pada Tanah Masam Ultisol. Jurnal Solum, 9 (2): 98-105.

Arwiyanto T. 2003. Pengendalian Hayati Penyakit Layu Bakteri Tembakau. Jurnal Perlindungan Tanaman Indonesia 3(1): 5460.

Badan Perumahan dan Penanaman Modal Daerah Propinsi Kalimantan Timur. 2009. Investasi Budidaya Jeruk Borneo Prima. Samarinda (ID): BPPMD.

Erwanti, 2003. Potensi Mikroorganisme Tanah Antagonis Untuk Menekan Pseudomonas sollanacearum pada Tanaman Pisang Secara in vitro di Pulau Lombok. Makalah Falsafah Sains Program Pasca Sarjana (S3). (Tidak dipublikasikan).

Goenadi, D.H. dan R. Saraswati. 1993. Kemampuan Melarutkan Fosfat Dari 
Beberapa Isolat Fungi Pelarut Fosfat. Menara Perkebunan 61(3):61-66.

Metasari, K. 2011. Eksplorasi Bakteri Penambat Nitrogen Non Simbiosis dari Tanah

Powell KA, Faull JL. 1989. Commercial Approaches to the use of Biological Control Agents. In Biotechnology Of Fungi For Improving Plant Growth. Ed. Whipp jm, Lumsden $r d$. Cambridge University Press. Cambridge. 259-275.

Simatupang DS. 2008. Berbagai Mikroorganisme Rhizosfer pada Tanaman Pepaya (Carica papaya L.) di Pusat Kajian Buah-buahan Tropika (PKBT) IPB Desa Ciomas, Kecamatan Pasirkuda, Kabupaten Bogor, Jawa Barat. [Skripsi]. Institut Pertanian Bogor, Bogor.

Sudantha IM, Kesratarta I, Sudana. 2011. Uji antagonisme beberapa jenis jamur saprofit terhadap fusarium oxysporum $f$. Sp. Cubense penyebab penyakit layu pada
Kawasan Mangrove Wonorejo Surabaya. Skripsi Thesis. Universitas Airlangga. http://repository.unair.ac.id. Diunduh tanggal 11 Februari 2016.

tanaman pisang serta potensinya sebagai agens pengurai serasah. UNRAM, NTB. Jurnal Agroteksos 21 (2): 2-3.

Susilowati, D.N., Rosmimik, R. Saraswati., R.D.M. Siman ungkalit dan L. Gunarto. 2003. Koleksi, Karakter isasi dan Preservasi Mikroba Penyubur Tanah dan Perombak Bahan Organik. Prosiding Seminar Hasil Penelitian Rintisan dan Biotehnologi Tanaman, Bogor.

Widiastuti H, Siswanto, Suharyanto. 2010. Karakterisasi dan Seleksi Beberapa Isolat Azotobacter sp. untuk Meningkatkan Perkecambahan Benih dan Pertumbuhan Tanaman. Buletin Plasma Nutfah 16 (2): 160- 167. 